\title{
Social Studies Education: Panacea For National Development
}

\author{
Osalusi, Florence Modupe PhD \\ Department of Educational Foundations and Management, Faculty of Education, \\ Ekiti State University Ado-Ekiti, Nigeria. \\ Email: osalusiflo2009@gmail.com
}

\section{Doi:10.5901/mjss.2014.v5n23p2530}

\section{Abstract}

\begin{abstract}
The socio-political and economic changes in the world and within nations have brought about changes in educational goals. To this end, schools are called not only to equip the learners with basic knowledge but also with problem-solving and thinking skills that could lead to self-development of learners and eventual national development. This paper examined how Social Studies contents could be utilised to give learners all round development with a view to making meaningful contributions to the development of the country. Issues such as Education and self-reliance; Social Studies and national development and The role of Social Studies teachers towards national development were critically examined. Nigerian society was in focus in this paper. The paper concluded that the development of desirable attitudes among the people is essential in order to enjoy the benefits inherent in Science and Technology. Part of the recommendations made was that University and Research Institutes in the country need to preach the promotion of the right type of attitudes in their works; The teaching of Social Studies should be handled by experts knowledgeable in the unique methods, techniques and strategies required for its teaching and that there is need to improve existing infrastructural facilities in the country, as well as build new ones to attract foreign investors for national development.
\end{abstract}

\section{Introduction}

In all human aspirations, the quest is always for greatness all over the world, and Nigeria seems to be no exception. One of the five National objectives constantly kept in view is that, Nigeria's education system should be able to assist her to become a "united, strong and self-reliant nation". (FRN, 2004). To attain self-reliant status is a worthwhile goal but its pursuit and attainment requires dedication, determination, perseverance and honesty of purpose by all concerned as well as disciplined citizens. This is where Social Studies education comes in. Anders (2010) asserts that Social Studies as a school discipline should help all individual members of a society develop the ability to adapt to their ever-changing environments and produce citizens who are well disciplined, loyal, obedient, honest, hardworking, dedicated, committed and painstaking. These virtues are essential in making citizens capable of contributing to the "building of a free and democratic society; a just and egalitarian society; a united, strong and self-reliant nation; a great and dynamic economy and a land of bright and full opportunities for all citizens".

The above virtues are included in the contents of Social Studies and are in line with Nigeria's goals and aspirations on education for national development. TESSA (2007), posited that teaching and learning should involve helping learners to discover certain facts or answers to a given problem and this idea was equally supported by NTI (2009). However, many times learners depend on teachers for all the answers they need. This is not helpful in this modern world where every nations of the world moves in jet speed on developmental issues. The contributions of science to the economic prosperity, technological growth and advancement of a nation cannot be under estimated in this respect. This is more so, viewing the success recorded by countries like Japan, United States of America and Chinese in the area of science and technology. Ogunniyi (1983), reporting these achievements writes about Japan: "Japan's entry into the scientific and technological age is not an accident; It is the result of well Planned science education, Programme - a Programme, Inspired and sustained by, An intellectual tradition and An enlightened political leadership".

What the above quotation implies is that, in spite of the innumerable influence of science and technology on a nation's advancement, one discovers that there are many factors that tend to militate against the growth and development of science and technology in a country. This explains why in Nigeria, in spite of several years of attempted promotion of science and scientific activities and the development of general scientifically literate individuals such as Doctors, Engineers, Scientists, Architects etc., the nation is still not technologically matured. One tends to agree with the assertion that, political independence not accompanied by economic independence is a sham. Nigeria which recently marked her $54^{\text {th }}$ year of political independence is still far behind in the level of expected economic development in spite of 
her numerous human and natural resources. This might not be unconnected with the high level of corruption in her social and political life which in turn makes the country dependent on foreign experts for the construction of roads, building of dams, and other infrastructural facilities essential for national development. It is observed that the various undisciplined attitudes of the citizens such as ethnicity problem, religious intolerance, excessive materialism, armed robbery, laziness, lack of respect for constituted authorities, elders and irresponsibility by holders of public offices calls for a great concern if all the economic developmental efforts of the various tiers of government of Nigeria for self-reliance will not be in vain.

It could be argued that no nation is self-sufficient since all nations rely on one another in their corporate existence. However, there are differences in the level of dependency to the extent that some nations are seen as client-states in all areas of their development. In Nigeria, there is inefficient water and electricity supply and poorly performed jobs, all of which constitute a drain on the public funds. As posited by Adefabi (2002), we cannot say that Nigeria lacks the required man-power to make her great because this is a country where there are highly rated world-class scientists, many parading national and international honours but still suffers the burden of foreign experts. One cannot but conclude that something is wrong somewhere in the case of Nigeria economic development for self-reliance. Therefore, the focus of this paper is on how Social Studies contents could be taught effectively in making Nigeria to become a self-reliant nation.

\section{Education and Self-Reliance}

Education has been given different interpretations by educators. Oluwoye (1988), described education as a process which is supposed to make an individual become functional and productive members of the society, develop moral character and mental powers of the people. Many educators, (Oke \& Jekayinfa, 2003; Utulu, 2007), agreed that education is the key by which a country can unlock the 'padlock' to economic freedom and self-reliance as an independent politically sovereign nation. Hence, education is inseparably linked with the deepest problems of national destiny.

In Nigeria, education is not tied to ability to read and write or acquire skills or success in examinations. It is observed that a man can be a complete failure in life in spite of successes in examinations if he lacks good character, qualities such as honesty, diligence, patriotism and humility which are essential to true success in life. For instance, a trained and well equipped police officer who for personal reason decided to use the tools available to him for performing his legitimate duties of defending the nation to engage in armed robbery could not be regarded as an educated person. Likewise a medical doctor who decline to answer promptly an emergency call could not also be regarded as a citizen who is making positive contributions towards a self-reliant nation. Social Studies has been observed to be capable of correcting these imbalances in peoples' attitudes if its contents are appropriately disseminated.

Self-reliance could be viewed as trusting in or having absolute confidence in oneself. It could also be interpreted to mean to depend entirely on one self for a living and a measure of one's success in life. There is a close linkage between education and self-reliance. In any profession, apart from external factors, the degree of correlation between education and self-reliance varies directly as the level of education acquired (Oluwoye, 1988). It is observed that most African countries, Nigeria inclusive, are 'competing beggar nations'. They vie with one another for favours from their former colonial masters of Europe for their existence and development in terms of food supply, grants, aids. This is done to the extent that their existence and destiny are controlled directly or remotely by those their benefactors (neo-colonialists). It is observed that there are many different social orientations leading to economic and educational imbalance in Nigeria hence, the key to unlock all these for national development is education.

\section{The Role of Social Studies towards National Development}

Nigeria as a country has its peculiar social characteristics and problems. The country consists of over 250 ethnic groups, each with its own identity and value systems. The society itself is bedevilled by indiscipline and social vices which make the realisation of the goal of 'a united, great and self-reliant nation' unattainable. This is where the relevance of Social Studies comes in. Social Studies as an area of study (Ogundare, 2000) is centrally based on societal issues with problems of the people in an environment as the central core. The National Council for Social Studies (NCSS,2010) sees Social Studies as providing coordinated, systematic study drawing upon such disciplines as Anthropology, Economics, Geography, History, Law, Philosophy, Religion, and Sociology as well as Mathematics and Natural Sciences. This is with a view to addressing issues of the society in holistic way in order to arrived at the true position on problems of the society. The various views expressed indicate that, Social Studies examine people comprehensively having in mind the totality of the realities of man's existence.

Social Studies as pointed out earlier can be seen as an instrument of change and development for both the 
individual and the country as a whole. It is an innovation brought to Nigeria from Britain and America after series of workshops organised to share the successes recorded in these countries through the contents of Social Studies. This was use to correct the unbalance attitudes of citizens in the two countries with a view to bringing economic development into their countries. Johnson and Johnson (2002) asserts that all individuals in a society need to know the factors that contribute to who they are; to what they think, feel, and believe; to what they decide and do; to why they are likely to make certain decisions and act in particular ways; and to how they perceive themselves, their abilities, their personality, and the world. Argote, (2000) observes that in the process of development, we must recognize that no modern society is self contained and self sufficient, hence the need to understand the relationship between our society and the rest of the world community.

Experience has shown that the fact that we want so many things means that we do not have them, and that, it is the lack which has created problems in our society. Modern development comes through Science and Technology and these can only be acquired through dedication, hard work, high sense of cooperation, discipline and responsibility, all of which centre on correct attitudes to life generally. Social Studies is capable of improving attitudes, developing citizens with correct views of the need of a country, and those who have a high sense of national pride and commitment to give the quality of character, correct and proper attitudes with which the problems of the society could be solved in course of time in this country. It has been argued that the legitimate contribution which Social Studies has to offer a child can best be considered in relation to the ultimate purpose of education in Nigeria. Osakwe and Itedje (1993), share this opinion by saying that:

"the goals of Social Studies education may be said to be co-terminus with those of the entire school programme in its efforts to help young people to become responsible thinking feeling people".

National development of Nigeria aims at the attainment of general accepted standards and norms in respect of the nation's economic system, political organization, ethnic and religious relationship, family life and overall relations and responsibilities between the state and individual persons or communities. These objectives represent the types of knowledge, skills, attitudes and values which Social Studies for Nigeria schools aim at inculcating in the youths. It can hereby be vitalized that Social Studies is one of the areas of study through which National objectives on education can be achieved.

\section{Social Studies Teachers and National Development}

The Federal Government of Nigeria believes that, education is an essential investment that a nation can make for the quick development of its economic, political, sociological and human resources. Hence, the National Policy on Education, revised edition (2004), in its preambles, clearly stated that education has become of great concern to the government in its ability to transform the Nigerian society. Therefore, the broad educational objectives form the bases from which all levels of education derived their various curricula objective, Social Studies inclusive. These days, our society exists in a troubled world, saturated with urban technological and industrial related problem, riots, violence and so on. The need then arise for children to make necessary adjustment to live productive, happy lives, accept change and be able to deal with it thoughtfully and intelligently. Social Studies seems to be the answer to achieve these for a country such as Nigeria.

It has been argued that the legitimate contributions which Social Studies have to offer a child can best be considered in relation to the ultimate purpose of education in Nigeria. For instance, Osakwe (1993) was of the opinion that the goals of Social Studies education may be said to be coterminous with those of the entire school programme in its efforts to help young people to become responsible thinking-feeling people. From the foregoing, one could rightly conclude that Social Studies objectives and Nigerian's national objectives on education are "two side of the same coin" and it is through the successful attainment of these objectives that the nation could be self-reliant. The issue at stake is whether the contents of Social Studies curriculum are being implemented the way they should in accomplishing the valuable objectives.

Miranda (2000) was of the opinion that, to teach is not to assert that what is taught is true but also to subject it to clarification and explanation as to why it is true. He went further to say that, to ensure this, there is the need for teachers who are more than classroom technicians; who are sensitive to human needs; who are culturally aware; who can plan and develop learning materials; and who are creative and also create learning environments in schools that permit students to act in these ways. He submitted that learning is too important to be left in the hands of incompetent or insensitive individuals. In Nigeria presently, it is observed that many people are in the classroom who are engaged in little but the systematic destruction of young minds and feelings. Miranda (2000) believes that ministering to the part and not 
the whole is a sure-fire strategy for failure. Such piece-meal tinkering according to him is not only costly but both in the long and short term frustrating. Educators need to recognize the far reaching societal implications of the process we call schooling and move rapidly on a coordinated front to systematically remove practices that have negative consequences for students and staff. Therefore, it is required of Social Studies teachers to find a reasonable balance between having students cover a significant amount of contents and study topics in depth.

Akinlaye (1996) and Adewuya (2002), assert that in an attempt to perform their teaching tasks, most teachers depended much on the use of textbooks either to read facts from or to direct the attention of their students to pictures, maps and diagrams in them. Textbooks have replaced the valuable sources of information since survey maps, journals, dailies and old historical materials are not available and those materials that were available did not appear to be suitable and related to the topics and themes being taught. Another problem is the teachers' misconception about the meaning of integrated Social Studies and the difficulty of using required teaching approaches such as inquiry method, problemsolving, role playing, simulation among other recommended methods required for its effective teaching. If Social Studies programme calls as it did, for radical changes in contents and teaching approaches, then there is need for new techniques and strategies for teaching the subject in achieving its desired objectives for national development.

\section{Conclusion}

Attempt have been made in this paper to show the close relationship between education and self-reliance with particular reference to Social Studies education. It has also been established that the nation could attain its educational objectives, most importantly self-reliance with effective teaching and learning of Social Studies. From the discussion advanced earlier, it is the contention of this paper that remarkable efforts have been made in areas of science and technology in Nigeria, however, the development of desirable attitudes essential for achieving the objectives of science and technology for national development is still lacking among the peoples of Nigeria. The more reason why Nigeria is bedevilled by all sorts of social vices at all levels. Issues such as dishonesty, disloyalty, misuse of offices and public funds among others are rampant. From all indications, it should be noted that no country can attain greatness and be self-reliant with all these vices. Hence, effective teaching and learning of Social Studies is the answer!

The nation cannot continue to wait in order to make every one literate before we can move forward. There are other methods of providing information to the illiterates in the rural areas through the use of such materials like television, VCD, radio and sound tapes, film strips, photographs in areas of interest like agriculture, environment conservation, health, among others to improve the standard of living of the people and serves as greater mobilization towards several developmental projects among the people and the resultant effect that will no doubt lead to self-reliance.

\section{Recommendations}

1. In Nigeria presently, many universities and research institutes have been established. There is need to justify the huge investments of the government, corporate bodies and individual members of the country on these institutions. Therefore, there is need for our Universities and research institutes to promote the right type of attitudes in our citizens for good leadership in order to put Nigeria on the right path of achieving self-reliance.

2. Government at all levels need to take the teaching of Social Studies more seriously in our schools by enforcing policy that will ensure that experts trained in the right methods, techniques and strategies for its effective teaching handle the subject in order to attain the desired objectives for national development.

3. There is need for an improvement in the infrastructural facilities such as the existing industries and factories, roads, power supply and potable water to encourage foreign investors to have confidence in investing into the nation's economy. This in turn might guaranty self-reliance of the nation.

4. Unemployment of youths should be vigorously addressed to check crime and for the young school graduates to have opportunity to make positive contributions to the development of the country.

\section{References}

Adewuya, S.A. (2002). "Principles and concept of Social Studies": Ado-Ekiti: Yemi Publishing co. Ltd.

Adefabi, R.A. (2002). National Economic life in lyela, A. et al (Eds): An Introduction to Social Studies. Vol.1, Lagos: Lagoon Publishers.

Akinlaye, F.A. (1982). "Meaning and concepts of Social Studies": Social Studies teaching issues and problems. Benin: Ethiope Publishing Corporation.

Anders, W. (2010). Engaging Pedagogies in Elementary Social Studies. USA National Council for Social Studies (NCSS). 
Argote, L. (2000). "Knowledge transfer in organisations: Learning from the experience of others" Organisational Behaviour and Human Decision Processes 82(1), 1-8.

Federal Republic of Nigeria (2004): National Policy on Education (4th $e d)$ Nigeria: NERDC press.

Miranda, S.A. (2000). Service -learning: An essential component of citizenship education. Social Education 65 (4), $240-241$.

NCSS (2010). "What is Social Studies and Why is it Important?": Nation Curriculum Standards for Social Studies; A Framework for Teaching, Learning and Assessment. U.S.A., National Council for Social Studies.

N.T.I. (2009). Manual for the re-training of Primary school Teachers Social Studies. A Millennium Development Goals project. Kaduna.

Ogundare, S.F. (2000). Foundations of Social Studies - A handbook of concepts and principles of Social Studies. Ibadan: Adesesan Press.

Ogunniyi, M.B. (1983). Science Education: The Basis to Realistic Scientific and Technological Development of Nigeria. A Paper Presented at the 24th Annual Conferences of Science Association of Nigeria.

Oke, C.S,\& Jekayinfa, A.A.(2003). Sociology of Education. Owode, Oyo. Tobistic Printing and Publishing Ventures.

Oluwoye, S.A. (1988): Education for Self-reliance. A Paper Presented at the First Annual Conferences of the Nigeria Association of Professional Educator (NAPE) Ondo State Chapter at Ikere-Ekiti.

Osakwe, E.O. and Itedje, P.O. (1993). Social Studies for Tertiary Students in Nigeria NEWAGE Publishers, Enugu.

TESSA, (2007). Life Skills Supporting Teachers to Achieve Education for All. Kaduna: NTI press.

Utulu, R.E. (2007). Patterns of Curriculum Organisation: in the curriculum and the Teacher: Theory and Practice. Second Edition, Makurdi. Selfers Publishers. 